\title{
EFL Teachers' Beliefs and Practices About Learner Autonomy
}

\author{
$1^{\text {st }}$ Nunung Nurhayati \\ English Education Study Program \\ STKIP Setiabudhi Rangkasbitung \\ Indonesia \\ uminoureen01@gmail.com \\ $4^{\text {th }}$ Habib Cahyono \\ English Education Study Program \\ STKIP Setiabudhi Rangkasbitung \\ Indonesia
}

\author{
$2^{\text {nd }}$ Obay Jambari \\ English Education Study Program \\ STKIP Setiabudhi Rangkasbitung \\ Indonesia \\ $5^{\text {th }}$ Puji Siswanto \\ English Education Study Program \\ STKIP Setiabudhi Rangkasbitung \\ Indonesia
}

\author{
$3^{\text {rd }}$ Berita Mambarasi Nehe \\ English Education Study Program \\ STKIP Setiabudhi Rangkasbitung \\ Indonesia \\ $6^{\text {th }}$ Arief Styo Nugroho \\ English Education Study Program \\ STKIP Setiabudhi Rangkasbitung \\ Indonesia
}

\begin{abstract}
This paper aims to find out the certified and non-certified teachers' beliefs and practices about learner autonomy in the EFL classroom. The findings revealed that there is not a huge differences between the certified and noncertified teachers' beliefs and practices of learner autonomy. It was also found that both the certified and non-certified teachers' understanding about learner autonomy are not salient with the literature.
\end{abstract}

Keywords-Teachers' beliefs, actual practices, learner autonomy

\section{INTRODUCTION}

Considering the benefits of learner autonomy, it becomes a prominent issue to be investigated and has been studied widely. The benefits of learner autonomy is providing students with the learning activities that lead them to be more responsible learner and life-long learning skills [1]. Due to its benefit, learner autonomy becomes an ultimate goal in education in general and foreign/second language in particular [2]. Therefore, promoting learner autonomy in an EFL classroom is a must.

Regarding to the learner autonomy promotion, it is challenging.Vázques[3] reported that the learner autonomy promotion is hardly a reality in many schools and the difficulty might be as the result of a dearth of teacher education program focusing teacher and learner autonomy. In addition, it might be because of educational system [4], contextual challenges regarding the student, teacher, institution, and culture [5], and teacher's beliefs [1]. In the terms of the teacher's beliefs, according to Borg [6], the teacher's beliefs influence his/her practices. The teacher's beliefs is demonstrated in his/ her teachinglearning activities. In the terms of learner autonomy practice, Ahmadianzadeh, Seifoori, \&Tamjid[7] stated that it relies heavily on teachers' beliefs. Therefore, understanding the teacher's beliefs about learner autonomy is needed.
Related research on the teacher's beliefs and practices about learner autonomy revealed that the teachers had different beliefs regarding the learner autonomy [1], [8]; and [9]. Besides, the teachers' practices regarding the learner autonomy were not in line with their beliefs. One of the causes of beliefs and practices inconsistency was lack of learner autonomy knowledge [8]. The teachers did not have sufficient knowledge related to learner autonomy. In order to have a wide knowledge and information, the teacher may join teacher professional development such as workshop, certification program, and to mention a few.

In Indonesian context, the certification program aims at improving the teacher's knowledge and teaching skills. It also serves as 'an official recognition quality for teachers who have reached the standards endorsed by the education authorities and serves as a mark of a teacher's competence in subject-matter knowledge and teaching methodology' [10]. Thus, the teacher who has passed the certification program, the certified teacher, is recognized as the qualified and competent teacher while non-certified teacher is less-skilled teacher.

With reference to the importance of learner autonomy promotion, the influence of teacher's beliefs toward practices, and certified and non-certified teachers classification, this study is conducted. It aims at investigating the EFL certified and non-certified teachers' beliefs and practices about learner autonomy.

\section{METHOD}

Two English teachers of vocational senior high schools were the participants in this study. Both of them are female. Both of them had experienced teaching English for 15 years. Teacher $\mathrm{A}$ is the certified teacher and she is 37 years old. Teacher B is non-certified teacher and 38 years old. In collecting data, classroom observations and semi structured interviews were employed. I observed the teachers' actual practices in the 
classroom for two meetings. The observation scheme is based on the autonomous classroom theory from Dam[11], learner autonomy perspective from Benson [12], and sociocultural perspective from Oxford [13]. The observational data were analyzed based on what Borg [6] termed key instructional episodes; these are classroom incidents that demonstrate or challenge the teachers' autonomy in practice. For the interviews, I asked them their understanding and beliefs about learner autonomy, and their underlying reasons of their actual practices.

\section{FINDINGS AND DISCUSSION}

\section{A. Teachers' beliefs about learner autonomy}

Both teacher A and B defined learner autonomy as a learning without teacher. The finding is similar to Lengkanawati's study [8]. Their understanding about learner autonomy includes to a learner autonomy misconception. Little[14]stated some misconceptions and one of them is understanding learner autonomy as learning without teacher. However, autonomy is not "a matter of deciding to learn without teacher" [14] (p.3). In addition, the development of autonomy implies collaboration and interdependence, rather than working in isolation [15][16]. Furthermore, teacher B stated that learner autonomy occurred when the teacher could not come to the classroom and he or she gave students an assignment. Her statements showed that learner autonomy is a kind of teaching method when the teacher is absent in the classroom. Nevertheless, learner autonomy is no a teaching method. It is a capacity "the capacity to take control of one's learning [12] (p.58). It means that the learner is responsible for their own learning related to "determining the objectives, defining the contents and progressions, selecting methods and techniques to be used, monitoring and evaluating what has been acquired" [17](p.3). Their understanding shows their limited understanding about learner autonomy. When I asked them about their understanding about learner autonomy, both of them replied that they do not know more deeply about learner autonomy because they never join learner autonomy workshop. Besides, they were never chosen to be a delegation to join a teacher professional development held by government. They also added that they do not have enough time to read article related to learner autonomy since they have to teach from 7 a.m. up to 4 p.m.

In the terms of their beliefs about learner autonomy, both of them were positive on learner autonomy. They agree that promoting learner autonomy in the classroom is their duty. They stated that their duty is not only teaching about English but also promoting learner autonomy because creating an autonomous learner is one of Curriculum 2013 objectives. They believed that learner autonomy as an investment for students. Teacher A stated "students' future life is hard, so they have to be independent, do not rely on others. That's why we have to teach them to be autonomous students". In addition, they also believed that their current students were not autonomous. It was due to their students' laziness to learn at home and to read topic before the class started. Besides, the students relied much on teacher. Teacher A stated
"Although I asked them to bring an English dictionary, they did not do it because they are lazy and for the word meaning, they prefer ask the teacher rather than look for in the dictionary".

Not only students' laziness, but also limited school facility is a hindrance factor in promoting learner autonomy. Both teacher A and B claimed that in-focus unavailability for each class is one of a burden. Teacher A stated that she got difficulty in illustrating something without in-focus. In a similar vein, teacher B said "Actually, I want to show an interesting thing such as video, but in focus is not available. So, it is a problematic situation". They see school facility related to the technology and self-access center which are provided by a school.

\section{B. Teachers' actual practices}

In the observation, I observed twice for each teacher. For teacher A is reading and grammar class while Teacher B is grammar and writing class. The observations presented that both teacher A's and B's actual practices seemed to be teacher-centered. First, it was seen from the seating arrangement. All the students' desks are facing teacher's desk and whiteboard. The physical classroom appearances shows that teacher as a central of teaching-learning activity.

Second is teaching-learning activities. The procedures were checking the students' attendances, telling the topic would be learned, asking students to open certain page of their English books, explaining the topic, asking students to do exercises, and concluding the lesson. During teaching-learning process, the students asked the teacher difficult word meanings and the teacher answered directly. The teacher also corrected the students' wrong pronunciation. Such learning procedures do not provide students with opportunity to be autonomous students. Besides, those teachers seldomapply grouping activity. Teacher A stated that she applied group/pair activity for speaking class. In her speaking class, she asked her students to read the dialogue in pairs. Whereas teacher B stated that she used group work for certain topic such as 'greeting card'. Teacher B emphasized her teaching on teaching grammar. It was based on her learning experiences. Learning English means learning the rules or grammar. Nonetheless, in promoting learner autonomy, student-centered should be applied. Besides, the practices should be related to the four perspectives of learner autonomy, technical, psychological, political and sociocultural [12]. The technical perspective is related to learning outside classroom and out-of-class-task using internet. The psychological perspective deals with the learner's characteristics such as confidence, motivation and so on. The political is on learner right on deciding their own learning. The sociocultural emphasizes the interaction between learner and his/her environment. During teaching learning,

Third is teachers' roles during teaching learning process. Both the teacher A and B played asa controller. The teacher role in learner autonomy is not similar to traditional classroom setting. The teacher's roles in fostering learner autonomy is "in terms of a continuum 
from transmission to interpretation teaching" [12](p.185). Furthermore, theydid not involve their students in deciding the learning objectives, activities, and assessment since it is a teacher's duty. Teacher B stated "I do not involve my students to decide learning aim because it has been set by the government and I as a teacher should follow it". Furthermore, teacher A stated that the students were not confident to decide those learning aspects. In the terms of assessment, they claimed that it was a teacher authority. Therefore, they did not apply learner reflection as a means of learning assessment. However, learner reflection is a fundamental principle of the learner autonomy [18]. In assessing students' progress, they employed exercises or homework stated on the book. Thus, their assessment focused on mainly recalling the information.

Overall, both teacher A's and B's actual practices are far from learner autonomy concept. When I asked them why. They replied that they do not know how to promote learner autonomy in the classroom. They said that they do not know about learner autonomy. They also added that they never join workshop related to learner autonomy.

\section{CONCLUSION}

So far, the findings shows that no differences between certified and non-certified regarding their beliefs and practices about learner autonomy. Both of them have limited understanding about it and their beliefs influence their teaching practices in the classroom. Since they have misconceptions about learner autonomy and insufficient knowledge about it, learner autonomy workshop should be conducted.

\section{REFERENCES}

[1] S. Borg and S. Al-Busaidi, "Teachers' beliefs and practices regarding learner autonomy," ELT Journal, vol 66, no. 3, pp. 283-292, 2012a.

[2] P. Benson and J. Huang, "Autonomy in the transition from foreign language learning to foreign language teaching," D.E.L.T.A, pp. 421-439, 2008.

[3] B. Vázquez, "Teacher development for learner autonomy: An exploratory review of language teacher education for learner and teacher autonomy.," Innovation in Language Learning and Teaching, 2016.
[4] C. Balçıkanlı, "Learner autonomy in language learning: Student teachers' beliefs," Australian Journal of Teacher Education, vol. 35, no. 1, pp. 90-103, 2010.

[5] Y. Wang and W. M, "Developing learner autonomy: Chinese university EFL teachers' perceptions and practices," in Language Learner autonomy: Teachers' Beliefs and Practices in Asian context, R. Barnard and J. Li, Eds., IDP Education Ltd, 2016.

[6] S. Borg, Teacher cognition and language education: Research \& practice, London: Continuum, 2006.

[7] B. Ahmadianzadeh, Z. Seifoori and N. Tamjid, "Exploring EFL teachers' beliefs about and practices of learner autonomy across experience and licensure," Innovation in Language Learning and Teaching, pp. 1-18, 2018.

[8] N. Lengkanawati, "Learner autonomy in the Indonesian EFL settings," Indonesian Journal of Applied Linguistics, vol. 16, no. 2, pp. 222-231, 2017.

[9] G. Doğan and İ. H. Mirici, "EFL instructors' perception and practices on learner autonomy in some Turkish universities," Journal of Language and Linguistic Studies, vol. 13, no. 1, pp. 166-193, 2017.

[10] I. Harjanto, A. Lie, D. Wihardini, L. Pryor and M. Wilson, "Community-based teacher professional development in remote areas in Indonesia," Journal of Education for Teaching, pp. 121, 2017.

[11] L. Dam, "In-service teacher education for learner autonomy. Independence, 43, 21-28.," Independence, vol. 43, pp. 21-28, 2008 .

[12] P. Benson, Teaching and researching learner autonomy, Great Britain: Routledge, 2013.

[13] R. Oxford, "Expanded perspectives on autonomous learners," Innovation in Language Learning and Teaching, vol. 9, no. 1, pp. 58-71, 2015.

[14] D. Little, Learner Autonomy, Dublin: Authentik Language Learning Resources Ltd, 1991.

[15] W. Littlewood, "Autonomy: An anatomy and framework," System, vol. 24 , no. 4 , pp. 427-435, 1996.

[16] W. Littlewood, "Defining and developing autonomy in East Asian context," Applied Linguistics, vol. 20, no. 1, pp. 71-94, 1999.

[17] H. Holec, Autonomy and foreign language learning, Oxford: Pergamon Press, 1981

[18] D. Little, "Language learner autonomy: Some fundamental considerations revisited," Innovation in language learning and teaching, vol. 1, no. 1, pp. 14-29, 2007. 